\title{
GENERATOR FUEL COST OPTIMIZATION USING ANT COLONY ALGORITHM
}

\author{
Indri Suryawati*, Sagita Rochman \\ Department of Electrical Engineering \\ University of PGRI Adi Buana Surabaya \\ *Corresponding email address: indri.suryawati@icloud.com
}

\begin{abstract}
Ant Colony Algorithm (ACA) is an optimization algorithm was inspired by ant behavior when searching for the shortest distance from the food center. In this study, ACA is used for power plants with a fuel cost fitness function. ACA can search destinations faster than conventional methods such as Lagrange. In this study ACA used the optimal power flow of six power plants in the Java Bali $500 \mathrm{KV}$ system, the optimization results reduced fuel costs by $23 \%$ and Lagrange $17.4 \%$ compared to real conditions.
\end{abstract}

Keywords: Ant Colony Algorithm, fuel cost fitness function and generator fuel cost

\section{INTRODUCTION}

The fuel cost of each generating unit is different due to several factors including the type of generator fuel. The distance of the generator in a power system that affects line losses. Many studies have developed various ways to optimize economical fuel costs. Starting from deterministic methods such as lagrange, undeterministic methods such as Genetic Algorithm (GA), particle swam optimization (PSO) and Ant Colony Algorithm (ACA) [1].

ACA is an algorithm inspired by nature in the behavior of ant colonies introduced first by Dorigo and Marco in 1996. Ants are able to sense their complex environment to find food and return to their nests by leaving the Pheromon substance on the route they traveled, the farthest route must have been a substance pheromone evaporates faster than the shortest route so that the next ant will follow the pheromon that has not evaporated or the shortest route. This behavior is adopted by ACA algorithm [2-5].

In this study ACA is used to minimize the generation costs. with real data of the Java Bali system $500 \mathrm{kV} 25$ bus six thermal generators.
The purpose of this study is to obtain a minimum fuel cost.

\section{THERMAL GENERATOR}

Thermal generators are drives use primary fuels such as Steam Power Plants, Gas Power Plants and Diesel Power Plants. The cost of generating fuel changes not linearly with increasing power output of the generator. The cost characteristics of thermal generation are defined by the second order polynomial function approach [6];

$\mathrm{H}_{\mathrm{i}}=\mathrm{a}_{\mathrm{i}}+\mathrm{b}_{\mathrm{i}} \mathrm{P}_{\mathrm{i}}+\mathrm{c}_{\mathrm{i}}\left(\mathrm{P}_{\mathrm{i}}\right)^{2}$

Hi is Thermal generator fuel input to- $i$ (liter/hour). Pi is Thermal generator fuel output (MW). a,b,c is thermal generator input-output constants. The output from the generator must meet the following constraint:

1. Limitation of power balance

$$
\sum_{i=1}^{n} P_{i}=P_{D}+P_{L}
$$

Where :

$$
\begin{aligned}
& P_{i}=\text { The power generated by the unit } i \\
& P_{D}=\text { Power Demand } \\
& P_{L}=\text { Power line losses }
\end{aligned}
$$

2. Limitation of minimum and maximum active power values

$$
P_{i} \min \leq P_{i} \leq P_{i} \max
$$

Where :

$P_{i} \min =$ The minimum power that a unit $i$ generator can generate

$P_{i} \max =$ The maximum power that a unit $i$ generator can generate

\section{ANT COLONY ALGORITHM (ACA)}

The ACO algorithm is composed of a number of $n$ ants working together that 
communicate indirectly through Pheromone. Each ant begins the journey of a randomly chosen point, one by one the existing point visited by the ant with the aim of producing a tour. The selection of points to be passed is based on a probability function, called the status transition rule by considering the visibility (inverse of distance) of that point and the number of Pheromones contained in the segment connecting the point. The shorter a tour produced by each ant, the greater the number of Pheromones left behind by the road. Pheromone evaporation is intended to prevent stagnation, a situation where all ants take the same tour. The pheromone update is shown in equation (2.4) below:

$$
\tau_{r s}=(1-\rho) \tau_{r s}+\sum_{z=1}^{w=1} \Delta \tau_{r s}^{k}
$$

\section{RESEARCH METHODS}

In this research, optimizing the generator fuel cost using ACO is simulated using the 2016 MATLAB program, I5 computer with $4 \mathrm{gb}$ of memory. The results of the ACA will be compared with deterministic calculations, namely lagrange. With the Flowchart from ACA can be seen in Figure 3.1

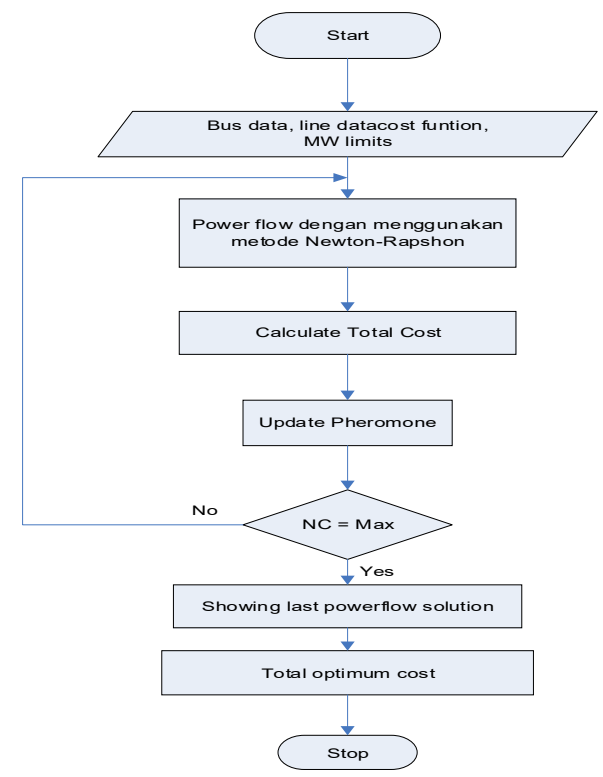

Figure 3.1 flowchart ACO to optimize generator fuel costs

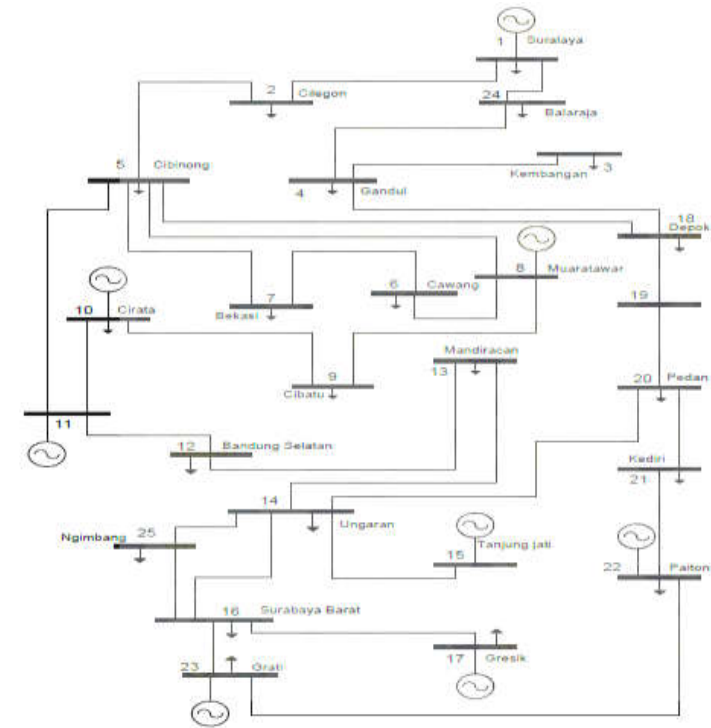

Figure 3.2 Single line diagram of the Java Bali System $500 \mathrm{KV}$

In this study using data from PT PLN (Persero) Java Bali on a 500-kV interconnection system consisting of 25 buses, 28 channels and 6 generators. These permits are Suralaya, Muaratawar, Cirata, Saguling, Tanjung Jati, Gresik, Paiton, and Grati. Cirata and Saguling power plants are hydropower plants so they are not included in the optimization. Single line diagram of $500 \mathrm{KV}$ Java-Bali interconnection system can be seen in the figure 3.2

Optimizations using the ACA method can be found in table 4.3 which will be compared with other calculation results. The Ant Colony calculation uses the following parameters:

- $\quad$ Number of $\mathrm{NC}=30$

- Rho =0,05

- $\quad$ Number of Ant $=50$

These parameters are determined based on ACO basic theory references and trial and error in this study.

\section{RESULT AND DISCUSSION}

Another factor influencing generation costs is the cost coefficient; shown in table 4.4 Data cost characteristics are obtained from design calculations or from measurement results. The operation of each thermal generating unit has a minimum and maximum critical operating limit. The minimum limit is due to the design of the generator that is unable 
BEST

Journal of Applied Electrical, Science, \& Technology - University of PGRI Adi Buana Surabaya

p-ISSN 2715-2871

e-ISSN 2714-5247

to operate under $30 \%$ of the design capacity. The maximum limit ranges from $80 \%-90 \%$ of the design capacity.

Simulation results using Java Bali $500 \mathrm{kV}$ 25 bus data, power and cost comparisons are shown in Figure 4.3a and 4.3b. The figure shows that each generator has very different cost characteristics because each generator has a different cost coefficient, for example, the Suralaya generator has a more expensive cost coefficient compared to Muaratawar and Paiton.

The power generated by each generator will significantly influence the difference in costs. Because the Java Bali $500 \mathrm{kV}$ system is a large system with a large cost coefficient and the range of input power per generator is also large so optimization is needed. Optimization with Ant Colony Optimization (ACO) is able to reduce costs by $23.4 \%$ while with lagrange only reduces the cost of generation $17.45 \%$. This is because lagrange is a conventional method based on lambda calculations and manual power equalization. While the ACO method uses the shortest distance tracking method in this case is the minimum cost.

Efficiency (small looses) does not guarantee a more economical cost, this depends on the length of the transmission, the type of power plant and the cost coefficient. Paiton for example has a low-cost coefficient but the distance to the load is far enough so that the increase in power at this plant causes an increase in looses.

Tabel 4.1. Cost coefficient and generator power range

\begin{tabular}{|c|c|c|c|c|c|}
\hline Generator & $\begin{array}{c}\text { Pmi } \\
\mathrm{n} \\
(\mathrm{M}\end{array}$ & $\begin{array}{c}\text { Pma } \\
\mathrm{x} \\
(\mathrm{MW} \\
\mathrm{W})\end{array}$ & $\mathrm{c}$ & $\mathrm{b}$ & $\mathrm{a}$ \\
& & & & \\
\hline Suralaya & 1500 & 3400 & 65.94 & 395668.05 & 395668.05 \\
\hline $\begin{array}{c}\text { Muarata } \\
\text { war }\end{array}$ & 1040 & 2200 & $\begin{array}{c}690.9 \\
8\end{array}$ & $\begin{array}{c}2478064.4 \\
7\end{array}$ & $\begin{array}{c}107892572 . \\
17\end{array}$ \\
\hline $\begin{array}{c}\text { Tanjung } \\
\text { Jati }\end{array}$ & 600 & 1220 & 21.8 & 197191.76 & 163648.18 \\
\hline $\begin{array}{c}\text { Gresik } \\
\text { Paiton }\end{array}$ & 238 & 1050 & $\begin{array}{c}132.1 \\
5\end{array}$ & 777148.77 & $\begin{array}{c}13608770.9 \\
6\end{array}$ \\
\hline Grati & 150 & 827 & 533.9 & 2004960. & 86557397. \\
& & & 2 & 63 & 4 \\
\hline
\end{tabular}

Table 4.2 Results of Calculation of Cost and Output Power

\begin{tabular}{|c|c|c|c|c|c|c|}
\hline \multirow{2}{*}{$\begin{array}{c}\text { Genera } \\
\text { tor }\end{array}$} & \multicolumn{2}{|c|}{ Original data } & \multicolumn{2}{|c|}{ Lagrange } & \multicolumn{2}{|c|}{$\mathrm{ACO}$} \\
\hline & $\begin{array}{c}\text { Pow } \\
\text { er }\end{array}$ & Cost & $\begin{array}{c}\text { Pow } \\
\text { er }\end{array}$ & Cost & $\begin{array}{c}\text { Powe } \\
\mathrm{r}\end{array}$ & Cost \\
\hline $\begin{array}{c}\text { P1 } \\
\text { Surala } \\
\text { ya }\end{array}$ & $\begin{array}{l}144 \\
2.92\end{array}$ & $\begin{array}{c}708239 \\
530\end{array}$ & $\begin{array}{l}254 \\
1.78\end{array}$ & $\begin{array}{c}143174 \\
8045\end{array}$ & $\begin{array}{c}3390 . \\
86\end{array}$ & $\begin{array}{c}209986 \\
0407\end{array}$ \\
\hline $\begin{array}{c}\text { P2 } \\
\text { Muarat } \\
\text { awar }\end{array}$ & $\begin{array}{c}176 \\
0\end{array}$ & $\begin{array}{c}660966 \\
5687\end{array}$ & $\begin{array}{c}148 \\
5\end{array}$ & $\begin{array}{c}531158 \\
4681\end{array}$ & $\begin{array}{c}1176 . \\
041\end{array}$ & $\begin{array}{c}397787 \\
5063\end{array}$ \\
\hline $\begin{array}{c}\text { P3 } \\
\text { Tanjun } \\
\text { g Jati }\end{array}$ & $\begin{array}{l}132 \\
1.6\end{array}$ & $\begin{array}{c}300461 \\
303\end{array}$ & $\begin{array}{c}122 \\
0\end{array}$ & $\begin{array}{c}274776 \\
623\end{array}$ & 600 & $\begin{array}{c}127828 \\
340\end{array}$ \\
\hline $\begin{array}{c}\mathrm{P} 4 \\
\text { Gresik }\end{array}$ & 900 & $\begin{array}{c}820084 \\
164\end{array}$ & 238 & $\begin{array}{c}206055 \\
683\end{array}$ & $\begin{array}{c}254.9 \\
43\end{array}$ & $\begin{array}{c}220326 \\
223\end{array}$ \\
\hline $\begin{array}{c}\text { P5 } \\
\text { Paiton }\end{array}$ & $\begin{array}{c}318 \\
0\end{array}$ & $\begin{array}{c}654825 \\
652\end{array}$ & $\begin{array}{c}325 \\
4\end{array}$ & $\begin{array}{c}682439 \\
576\end{array}$ & $\begin{array}{c}3180 . \\
372\end{array}$ & $\begin{array}{c}654962 \\
928\end{array}$ \\
\hline $\begin{array}{c}\text { P6 } \\
\text { Grati }\end{array}$ & $\begin{array}{c}398 . \\
6\end{array}$ & $\begin{array}{c}970564 \\
961\end{array}$ & 150 & $\begin{array}{c}399314 \\
692\end{array}$ & $\begin{array}{c}251.0 \\
72\end{array}$ & $\begin{array}{c}623603 \\
762\end{array}$ \\
\hline Total & $\begin{array}{l}900 \\
3.12 \\
\end{array}$ & $\begin{array}{c}100638 \\
41297\end{array}$ & $\begin{array}{c}888 \\
8.78\end{array}$ & $\begin{array}{c}830591 \\
9299\end{array}$ & $\begin{array}{c}8853 . \\
288\end{array}$ & $\begin{array}{c}770445 \\
6722\end{array}$ \\
\hline Looses & \multicolumn{2}{|c|}{$288.52 \mathrm{MW}$} & \multicolumn{2}{|c|}{$174.18 \mathrm{MW}$} & \multicolumn{2}{|c|}{$138.688 \mathrm{MW}$} \\
\hline
\end{tabular}

\section{CONCLUSION}

ACA can reduce the generation cost with average $5 \%$ than Lagrange method. ACA with a narrow search is easily trapped in optimum local.

\section{ACKNOWLEDGMENT}

The researcher thanked all the Electrical Engineering Study Program lecturers who had provided input, as well as the Dean of the Faculty of Industrial Engineering and the Head of the Electrical Engineering Laboratory of PGRI Adi Buana Surabaya University who had provided facilities in this research process.

\section{REFERENCE}

[1] Rosenkrantz, D.J, Stearns, R.E, dan Lewis, P.M. (1977). "An analysis of several heuristics for the traveling salesman problem," SIAM Journal on Computing, vol. 6, pp.563-581

[2] Dorigo, M., dan Gambardella, L. M. (1997). Ant colonies for the traveling salesman problem.

Tech.Rep/IRIDIA/1996-003, Université Libre de Bruxelles, Belgium

[3] M., dan Gambardella, L., (1996). Ant Colony System: A Cooperative learning Approach to the Traveling Salesman Problem. Tech.Rep/IRIDIA/1996-005, Université Libre de Bruxelles, Belgium 
[4] M., Maniezzo, V., dan Colorni, A.

(1996). The Ant System: Optimization

by a colony of cooperating agents. IEEE

Transactions on Systems, Man, and

Cybernetics-Part B, 26(1), pp.1-13.

[5] Dorigo, M., dan Socha K. (2007), An

Introduction to Ant Colony

Optimization, Tech.Rep/IRIDIA/2006-

010, Université Libre de Bruxelles,

Belgium.

[6] Djiteng Marsudi, 2006, "Operasi Sistem

Tenaga Listrik", Graha Ilmu,

Yogyakarta 